\title{
Correlation of Peer Assessment with Learning Achievement in Predict Observe Explain (POE) Learning
}

\author{
Widinda Normalia Arlianty ${ }^{\mathrm{a}, *}$, Beta Wulan Febriana ${ }^{\mathrm{a}}$ \\ ${ }^{a}$ Department of Chemistry Education, Islamic University of Indonesia \\ *Corresponding author: widindanormaliaarlianty@uii.ac.id
}

\begin{abstract}
This study aims to determine the correlation between peer assessment with learning achievement. The learning achievement was obtained from the value of chemistry practicum by taking three values, namely the value of responses and the pretest values taken using written test, and the value of practical skills taken using the peer assessment observation sheet. This research is a descriptive study. The sample of this research is second-semester student, force 2015/2016 Chemical Education Study Program, Islamic University of Indonesia. Data analysis using nonparametric statistic correlation test Spearman Rank Order Correlation. Based on statistical analysis, it is found that there is a correlation between peer assessment and student learning achievement: 1) correlation of peer assessment with response 0,722 ; correlation of peer assessment with pretest of 0.651 ; and the correlation of peer assessment with practical skills of 0.617 .
\end{abstract}

Keywords: correlation, peer assessment, learning achievement

\section{INTRODUCTION}

Education today is one important thing that must be considered in developing young generation. In education, a success will be obtained and can be seen through the achievement of learning. Through learning achievement, students' potential of learning activities in understanding the material and adapting to a particular curriculum can be known. In the field of learning, achievement can be obtained through a learning evaluation activities. Learning evaluation activities are meant to measure how far a person is able to receive the learning that has been obtained. Student achievement can be influenced by assessment method used. In recent years a lot of changes in the method of assessment, ranging from the development of assessment instruments and strategies that will be used [1, 2, 3]. In the learning activities, students must participate actively in it. Students are entitled to be involved not only in learning activities but also in the assessment process. The involvement of students in assessment activities is expected to assist students in spurring their self-awareness to improve student achievement. In addition, the development of current learning models such as cooperative learning, constructivist and scientific that requires students to mutually be able to work together in groups, and exchange ideas with each other, causing other students are entitled to give an assessment to fellow students because they experience the learning process together.

Academic achievement is a description of the control ability of learners. Learning achievement is expressed in scores of test results or numbers given by educators to their observations [4]. The learning achievement was also interpreted as a special level of skills acquisition or expertise in academic results are assessed by the teacher through tests [5]. The learning achievement is also a self-perception of the success of one's academic goals [6].

Peer assessment is the provision of feedback on the performance or value of friends [7]. Peer assessment is an assessment technique can be used to measure the level of achievement of competence attitudes by asking students to rate each other mutually. The instrument used may be the assessment form questionnaire. Peer assessment used in teaching in higher education requires some competencies 
possessed by students. These competencies include: 1) training students to be objective; 2) train students to have the ability and accuracy in assessing an object; 3 ) train students to have a sense of responsibility to be given the confidence to assess other friends [8].

Peer assessment can be used to assist students in developing the ability to work together, receive or provide feedback between friends, criticized the process and learning outcomes [9]. Application of peer assessment aims to provide feedback on a variety of learning activities, especially in learning achievement. Characteristics include peer assessment, peer assessment is a process whereby each member of a team doing assess, then goal setting should be understood students well. Peer assessment as an alternative assessment gives students the freedom to express opinions. Race and Bostock identified several advantages of peer assessment include: (1) peer assessment can improve the learning process, (2) to identify the weaknesses and strengths of students in learning, (3) encourage to learn more in-depth and meaningful (4) encourage the learning does not depend on others, (5) can recognize that transparent assessment criterion, (6) push for mutually analyzing the performance or results of each working group's friends [10].

Appropriate assessment of the target is always supported by the implementation of good learning. Good and quality learning is a learning that can make students become active in the process of science absorption and teachers only become facilitators only. Learning Predict Observe Explain (POE) is learning that emphasizes the development of science independently. Learning is done beginning with predicting stages, observing and ending by way of explaining. Through learning the POE students are trying to build their knowledge independently. With an active way in the learning process.

Assessment and learning outcomes are interrelated to one another. This is because an effort in the learning process will definitely result in an assessment in accordance with the business that has been done. Based on the above, the researchers tried to decipher the correlation between peer assessment and learning achievement in learning to use the model Predict Observe Explain (POE).

\section{METHOD}

\section{Design Research}

This research is quantitative research. Quantitative research is the systematic scientific study of the parts and phenomena and their relationships [11].

\section{Research Subjects}

The subject in this study were students of the department of chemistry education, Islamic University of Indonesia, the second semester of 2015 amounted to 41 people.

\section{Research Instruments}

The assessment instrument used to measure peer assessment correlation with learning achievement in POE learning consists of:

1. Measurement of posttest value using written test;

2. Measurement of pretest value using written test;

3. Measurement of the value of laboratory skills using observation sheet peer assessment.

\section{Data Analysis Technique}

The purpose of this study is to determine the relations between of two variables, namely peer assessment and academic achievement. Achievement learns in this research consist of three assessment, that is the value of posttest, pretest value, and laboratory skills value. In this study using Nonparametric statistical analysis because the data is not normally distributed. Analysis of data used is Spearman Rank Correlation analysis is nonparametric statistical analysis used to predict the relationship between independent variables and dependent variable [12]. So in this study, the correlation test used to measure: 1) Correlation between 
the peer assessment and the posttest value; 2) Correlation of peer assessment and pretest value, and 3) Correlation of peer assessment and value of laboratory skills.

\section{RESULTS AND DISCUSSION}

Based on nonparametric statistical analysis of test results by the Spearman Rank Order Correlation, correlation coefficient of two variables, namely peer assessment and learning achievement, namely 1) Correlation between peer assessment and posttest value of $0.617 ; 2$ ) Correlation between peer assessment and pretest value of 0.722 ; and) Correlation between peer assessment and value of laboratory skills of 0.651. Data can be seen in the Figure 1.

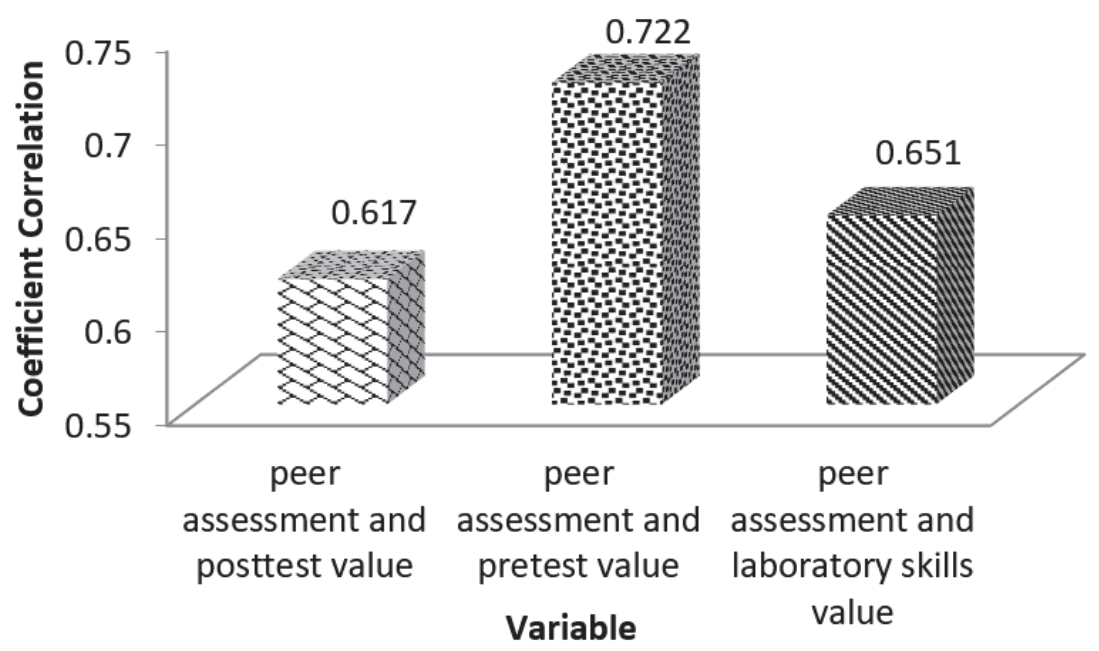

FIGURE 1. Coefficient Correlation Between Peer Assessment and Learning Achievement

Based on Figure 1. can explain the result of this research is the coefficient of correlation of peer assessment and learning achievement. The results of this correlation explain that the three peer assessment correlation with learning achievement there is a correlation both of them. The higher the peer assessment the higher the learning achievement students. Peer assessment of students has an effect on student achievement.

Peer assessment is an opportunity given to students in assessing their friends in the learning process. The opportunity was given to students to assess and provide feedback to their friends certainly cannot be misused. The educator governs the objectivity of the assessment by providing a judgment guide that is appropriate to the thing to be assessed. Peer assessment has advantages and disadvantages. Excess peer assessment: First, giving encouragement to students to always learn to get a good assessment. Second, it can increase the students' trust because they are given the authority to do the assessment without any difference. Third, giving place to the students in the learning arena, because when they do the assessment then the student is essentially learning to sharpen the insight about what they value. Fourth, increase the critical power of students because they are always searching and finding something carefully to be given notes or comments. Fifth, help students recognize criteria depth assessments and identify weaknesses and strengths which need to be held in learning [12]. While the shortcomings are the increase in the subjectivity of assessment due to the relationship of friendship, feelings of love, differences in social background, differences in gender responses, and lack of confidence and able to reduce group cooperation because of fear of conflict between the groups [13]. 
In a study conducted by Rochmiyati, the application of peer assessment can improve both cognitive skills and students' social skills [14]. Cognitive skills in the dimension of knowledge according to Anderson and Krathwohl consists of 1) factual; 2) conceptual; 3) procedural; 4) metacognitive (thinking about thinking) [15]. The existence of dimensions of knowledge consisting of four aspects in accordance with the research that has been done. This research was conducted in the course of the practicum in which there is already a procedure based on the knowledge dimension of cognitive skills.

In addition, the assessment used in this assessment using peer assessment is able to improve student cognitive skills. So it can be seen also the result that there is the correlation between peer assessment with student achievement in the laboratory because the application of peer assessment itself can improve cognitive skills that in student achievement itself. This is also reinforced by research conducted [16] that through peer assessment will awaken cognitive basics: 1) attention/memory; 2) function use of object/symbolic play; 3) problem solving/reasoning.

Peer assessment also has a positive impact on the success of learning where when peer assessment is effectively implemented in cooperative and elaborative learning can improve student achievement. This also reinforces the results of this study that in this study the learning is done using POE learners where in this learning is also one of the learnings that can support the creation of collaboration among students. Learning POE applied in practical learning in the laboratory is able to realize the cognitive skills of students who are able to meet the dimensions of knowledge among others; 1) Factual, learning experimental with $\mathrm{POE}$ and peer assessment conducted in the laboratory obtained results in accordance with the observed facts; 2) conceptual, the implementation of practicum activities with learning POE in the laboratory is done for the purpose of building student concepts based on the facts of the results of learning; 3 ) Procedural, POE learning conducted by experimental learning through procedures that have been established so that the results obtained real and accountable and this is able to help students to always think and build concepts based on learning in accordance with the last dimension of meta-cognitive (thinking About thinking).

\section{CONCLUSION}

Based on the results of research that has been done there is a correlation between peer assessment with student achievement on learning POE where for the correlation between peer assessment and posttest value of 0.617 ; Correlation between peer assessment and pretest value of 0.722 ; and correlation of peer assessment and laboratory skills value of 0.651 .

\section{ACKNOWLEDGMENT}

Authors would like to thank the Academic Development Agency (BPA) Islamic University of Indonesia who have given the opportunity to be one of the recipients Regular Teaching Grant Program in the second semester of the 2015/2016 academic year.

\section{REFERENCES}

1. A. Ahmadi, Psikologi Sosial (Rineka Cipta, Jakarta, 2009).

2. M. Syah, Psikologi Belajar (Raja Grafindo Persada, Jakarta, 2012).

3. D. F. Wood, BMJ, 8, 2, 328-330 (2003).

4. W. S. Winkel, Psikologi Pendidikan dan Evaluasi Belajar (PT. Gramedia Pustaka Utama, Jakarta, 2004).

5. J. P. Chaplin, Kamus Lengkap Psikologi translated by Kartini Kartono (Raja Grafindo Persada, Jakarta, 1999).

6. L. R. Coetzee, "The Relationship Between Student's Academic Self Concept, Motivation and Academic Achievement at The University of The Free State", Ph.D. Dissertation, University of South Africa, 2011.

7. N. Falchikov and J. Goldfinch, Rev. Educ. Res. 70, 3, 287-322 (2000). 
8. Kunandar, Penilaian Autentik: Penilaian Hasil Belajar Peserta Didik Berdasarkan Kurikulum (Raja Grafindo Persada, Jakarta, 2013).

9. G. Thomas, D. Martin, and K. Pleasants, JUTLP. 8, 1, 1-17 (2011).

10. S. Suryabrata, Metodologi Penelitian (Raja Grafindo Persada, Jakarta, 2011).

11. Riduwan, Dasar-dasar Statistika. (Alfabeta, Bandung, 2011).

12. S. Wahyuni and S. Ibrahim, Asesmen Pembelajaran Bahasa (Refika Aditama, Bandung, 2012).

13. G.J. Kennedy, Peer assessment in group project: Is It wort it? Paper appeared at The Australian Computing Education Conference Proceeding 2005, (The University of Sydney, 2005).

14. R. Rochmiyati, JPEP, 17, 2, 333 - 346 (2013).

15. L. W. Anderson and D. R. Krathwohl, Kerangka Landasan untuk Pembelajaran, Pengajaran dan Asesmen, translated by Agung Prihantoro, (Pustaka Pelajar, Yogyakarta, 2010).

16. J.Guo, X. Zhang, Y. Wang and A. Xeromeritou, IEJEE, 3, 3, 154-170 (2011). 